\title{
Perencanaan struktur rangka batang menggunakan metode building information modeling (BIM) dan konvensional
}

\author{
Sulaeman Fauji a,1, Paikun a,2,", Cece Suhendi a,3, Lisa Oksri Nelfia b,4 \\ ${ }^{a}$ Program Studi Teknik Sipil Universitas Nusa Putra, Cisaat, Sukabumi 43152, Indonesia \\ ${ }^{\mathrm{b}}$ Departement of Civil Engineering, Faculty of Civil Engineering and Planning, Trisakti University, Jakarta 11440, Indonesia \\ ${ }^{1}$ sulaeman.fauzi_ts16@nusaputra.ac.id*; ${ }^{2}$ paikun@nusaputra.ac.id*; ${ }^{3}$ cece.suhendi@nusaputra.ac.id, ${ }^{4}$ lisa@trisakti.ac.id \\ * Corresponding Author
}

\section{ABSTRAK}

Perkembangan teknologi berimbas juga pada bidang konstruksi, dalam hal ini perencanaan konstruksi beton bertulang Secara umum sistem struktur beton bertulang dinyatakan dengan kegunaan sistem, seperti struktur jembatan, gedung, tangki, dan bendungan . Perencanaan struktur beton bertulang sangatlah rumit ketika menggunakan metode konvensional. Maka itu, melakukan penelitian perbandingan Antara Metode Konvensional Dan BIM. Penelitian tersebut di dilakukan pada perencanaan gedung sekolah SMP IT AL-MULTAZAM yang berlokasi Di Kp.Tugu Desa. Wangunreja kec. nyalindung kab. Sukabumi. Dalam penelitian ini didasari dengan studi literature dari berbagai sumber Jurnal, Skripsi dan Buku . Hasil dari perbandingan Metode Tersebut . pada perencnaan struktur rangka batang metode konvensional langkah nya yaitu membuat gambar DED (Detail Engineering Design ) struktur menggunakan Sketh manual Aplikasi AutoCad,lalu melakukan Sketh dan analisis data di Aplikasi SAP2000 hasil data yang diproleh Mu,Vu,Pu terbesar, Setelah itu dilakukan Cek Tulangan Pu,Mu,Vu untuk pemenuhan Syarat Dalam tulangan Perencanaan Struktur Rangka batang dan pada perencanaan Struktur Rangka Batang menggunakan Sistem BIM yaitu pemodelan DED(Detail Enginering Design), penentuan penulangan secara otomatis Sesuai Dimensi, input pembebanan pada struktur Menggunakan Aplikasi sistem BIM Tekla Structure lalu RUN To SAP2000 output Memenuhi Syarat pada Struktur

\section{Planning of frame structure using building information modeling (BIM) and conventional methods}

\section{ABSTRACT}

Technological developments also have an impact on the construction sector, in this case the planning of reinforced concrete construction. In general, the system of reinforced concrete structures is expressed by the usefulness of the system, such as the structure of bridges, buildings, tanks, and dams. The design of reinforced concrete structures is very complicated when using conventional methods. Therefore, conducting a comparative study between conventional and BIM methods. The research was carried out in the planning of the ALMULTAZAM IT SMP school building located in Tugu Desa Kp. Wangunreja kec. nyalindung district. Sukabumi. This research is based on literature study from various sources of journals, theses and books. The results of the comparison of these methods. In planning the truss structure, the conventional method is to create a DED (Detail Engineering Design) structure image using the AutoCad Application manual Sketh, then perform Sketh and data analysis in the SAP2000 application resulting from the largest data obtained by $\mathrm{Mu}, \mathrm{Vu}, \mathrm{Pu}$, After that, a Reinforcement Check is carried out. $\mathrm{Pu}, \mathrm{Mu}, \mathrm{Vu}$ for fulfilling the requirements in the frame structure planning reinforcement and in the truss frame structure planning using the BIM system, namely DED modeling (Detail Engineering Design), automatic determination of reinforcement according to dimensions, loading input on the structure using the Tekla Structure BIM system application then RUN To SAP2000 output Meets Structure Requirements.

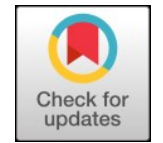

KATA KUNCI

Perencanaan struktur Rangka batang Metode BIM

Metode konvensional Struktur bangunan

\section{KEYWORDS}

Structure planning

Frame structure

BIM method

Conventional method

Building structure 


\section{Pendahuluan}

Sistem struktur didasarkan pada penggunaan hukum-hukum statika atau mekanika, serta mekanika bahan. Desain dari struktur beton bertulang tidak hanya guna memenuhi ketentuan atau persyaratan peraturan bagi konstruksi bangunan beton bertulang, tetapi juga untuk perencanaan optimal sistem serta rancangan yang ekonomis [1]. Secara umum sistem struktur dinyatakan dengan kegunaan sistem, seperti struktur jembatan, gedung, tangki, bendungan dan pesawat udara [2]. Secara khusus penamaan dibedakan dari fungsi sistem menerima beban luar [3]. Beton bertulang merupakan elemen utama pembentuk suatu struktur, beton bertulang terdiri dua unsur kombinasi tulangan baja dan beton yang digunakan secara bersama, sehingga desain struktur elemen beton bertulang dilakukan dengan prinsip yang berbeda dengan perencanaan desain suatu bahan [4]. Struktur beton bertulang banyak digunakan pada bangunan sekolahan dan bangunan lainnya [5]. Struktur beton bertulang merupakan struktur yang kompleks dan memerlukan banyak detail sambungan penulangan dan informasi-informasi detailang terkait dengan perencanaan pelaksanaan konstruksi [6]. Perencanaan dan pelaksanaan konstruksi, pada umumnya menggunakan metode konvensional yang sangat rumit untuk diterapkan dalam pendetailan dan penulangan [7]. Untuk mengatasi kerumitan metode konvensional dalam pendetailan pemodelan, maka perlu ada suatu solusi untuk mengatasi tingkat kerumitan tersebut, sehingga penelitian ini penting untuk dilakukan.

Berdasarkan permasalahan yang telah diuraikan, maka penelitian ini penting bertujuan untuk mngetahui perbedaan perencanaan struktur menggunakan metode konvensional dan metode BIM. Perbedaan metode pemodelan tersebut akan diterapkan pada perencanaan Struktur kerangka batang (portal) pada pembangunan sekolah SMPIT AL-MULTAZAM yang berlokasi di Kp.Tugu Desa. Wangunreja kec. Nyalindung kab. Sukabumi. Dengan jumlah lantai sebanyak 2 lantai dengan jumlah kelas sebanyak 6 kelas dan menggunakan struktur beton bertulang. Hasil penelitian ini diharapkan dapat berkonstribusi bagi masyarakat atau tim perencana proyek dalam merencanakan struktur bangunan, sehingga dapat menggunakan metode yang tepat agar perencanaan struktur dapat dikerjakan secara efisien berdasarkan mutu, waktu dan biaya.

\section{Metode}

Penelitian ini menggunakan metode eksperimen perencanaan struktur rangka batang menggunakan 2 metode yaitu metode konvensional dan metode BIM [8], yang bertujuan untuk membandingkan dari kedua metode tersebut yang paling tepat dalam melakukan perencanaan struktur. Tahapan penelitian ini dijelaskan lebih lanjut.

\subsection{Lokasi Penelitian dan Objek Penelitian}

Dalam penelitian ini penulis mengambil penelitian mengenai perencanaan Struktur Rangka Batang Beton Bertulang menggunakan 2 metode ini pada bangunan Gedung sekolah SMP IT Al-multazam yang berjumlah 2 lantai dan berlokaasi di kp. Tugu desa. Wangunreja kec. Nyalindung, Sukabumi, Jawa Barat. Objek penelitian yang akan diteliti adalah perencanaan struktur kolom dan balok beserta detail sambungan-sambungan struktur tersebut mengunakan metode perbandingan konvensional dan BIM.

\subsection{Pengumpulan Data}

Pengumpulan data-data primer perencanaan yang sudah ada berupa Gambar denah bangunan berupa denah dan 3D arsitektur pada pembangunan sekolah SMPIT Al-multazam. Data skunder merupakan penerapan dari berbagai sumber literatur, dalam hal ini penulis mengambil referensi dari berbagai naskah publikasi dari berbagai pakar didunia teknik sipil baik berupa jurnal, buku, skripsi maupun penelitian lainnya. Data yang dibutuhkan adalah data gambar perencanaan melipti; (1) Gambar denah perencanaan; (2) Gambar perencanaan 3D model, dan Data pembebanan yang dibutuhkan dalam penelitian ini adalah Beban Mati; Beban Hidup; Pembebanan pada Atap; Pembebanan pada Tangga; Pembebanan pada Plat Lantai; Beban Gempa (Respon Spektrum). Teknik pengumpulan data dengan cara Observasi Lapangan; Studi literatur; Wawancara.

\subsection{Analisis Data dan Pemodelan}

\subsubsection{Metode Konvensional}


Untuk Pemodelan dan Analisis data yang digunakan untuk mendapatkan respon struktur yang di rencanakan yaitu dengan metode Konvensional dengan menggunkan kombinasi pembebanan yang sesuai dengan SNI-1726-2012 [9] sebagai berikut:

$$
\begin{aligned}
& \text { 1,4 DL; } \\
& \text { 1,2 DL + 1,6LL; } \\
& \text { 1,2 DL + 1,0 LL + 1,0 EX + 0,3 EY; } \\
& \text { 1,2 DL + 1,0 LL + 0,3 EX + 1,0 EY; }
\end{aligned}
$$

Setelah dilakukan analisis maka diambil momen yang terbesar pada suatu elemen struktur yang berdimensi sama, sedangkan elemen lain dengan momen yang lebih kecil dianggap telah terwakili. Sedangkan untuk perhitungan tulangan dilakukan secara manual dengan memperhatikan kaidah-kaidah yang terkandung dalam Sistem Rangka Pemikul Momen Khusus (SRPMK) [10].

\subsubsection{Metode Sistem Building Information Modeling (BIM)}

Untuk pemodelan dan analisis data yang digunakan untuk mendapatkan respon struktur yang di rencanakan yaitu dengan metode Building Information Modeling (BIM) dengan menggunkan kombinasi pembebanan yang sesuai dengan SNI-1726-2012 [9] sebagai berikut:

$1,4 \mathrm{DL}$

$1,2 \mathrm{DL}+1,6 \mathrm{LL}$

$1,2 \mathrm{DL}+1,0 \mathrm{LL}+1,0 \mathrm{EX}+0,3 \mathrm{EY}$;

$1,2 \mathrm{DL}+1,0 \mathrm{LL}+0,3 \mathrm{EX}+1,0 \mathrm{EY}$

Untuk tulangan ditentukan secara otomatis oleh sistem aplikasi Building Information Modeling (BIM) dan untuk cek tulangan dan analisis combine dengan aplikasi sap2000 v16.

\subsection{Bagan Alir}

Metode dan tahapan penelitian ini secara ringkas disampaikan dalam bentuk gambar alur penelitin pada Gambar 1.

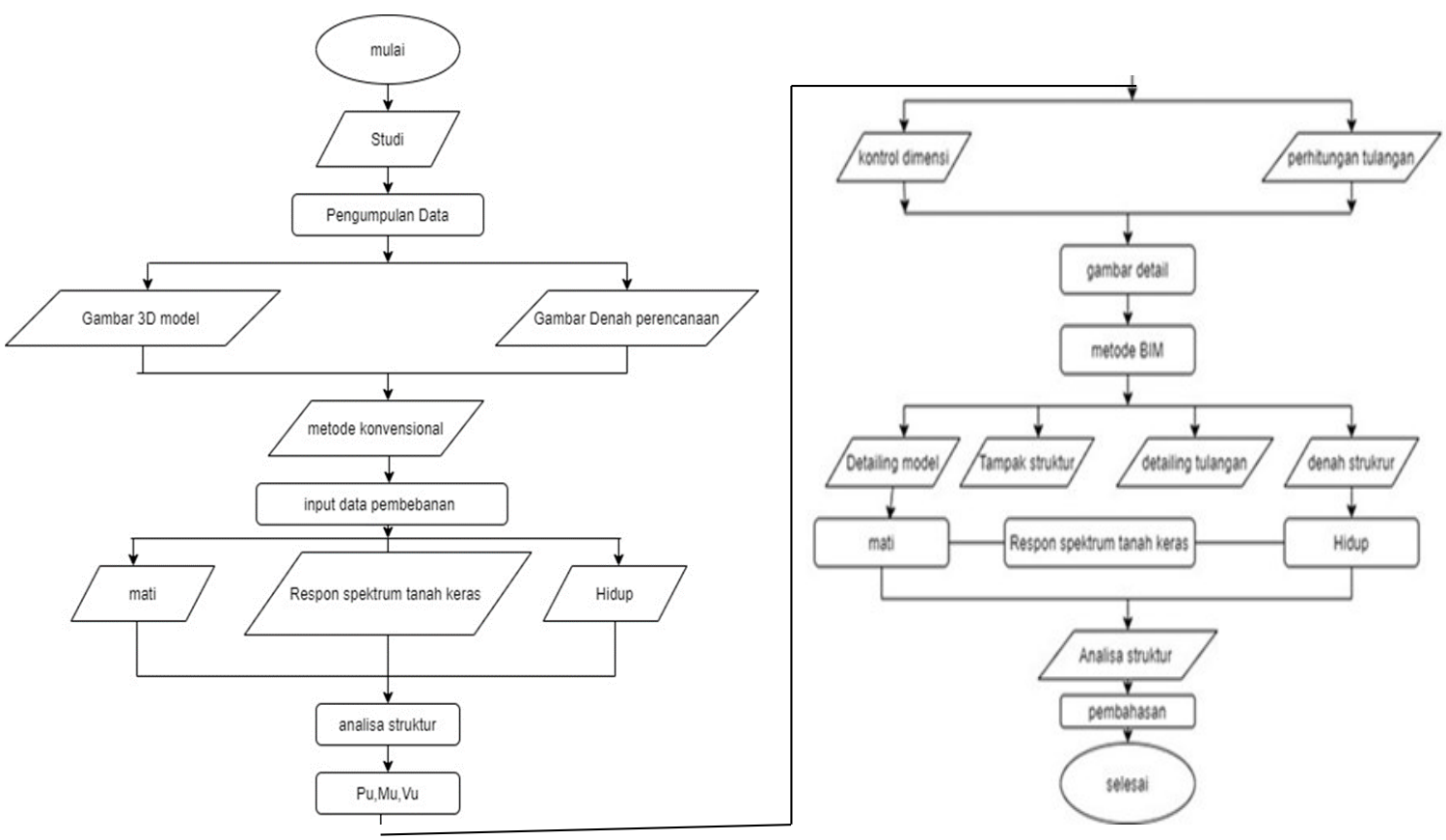

Gambar 1. Alur Penelitian 


\section{Hasil dan Pembahasan}

\subsection{Perencanaan Gedung}

Dalam penelitian mengenai perencanaan, pemodelan dan analisis struktur rangka batang tahan gempa menggunakan metode Building Informatiom Modeling (BIM) dan konvensional pada pembangunan Sekolah SMP IT Al-multazam dengan menggunakan Sistem Rangka Pemikul Momen Khusus (SRPMK). Dalam penelitian ini akan dilakukan analisis mengenai perbedaan metode sistem (BIM) dan konvensional. Data-data perencanaan yang didapat sesuai dengan pengumpulan data observasi dan wawancara dengan pihak sekolah yaitu berupa gambar denah dan 3D model sebagai gambaran utama dalam perencanaan struktur rangka batang tahan gempa. Denah dan perencanaan 3D model SMP IT Al-multazam yang direncanakan seperti dijelaskan pada Gambar 2 dan Gambar 3.

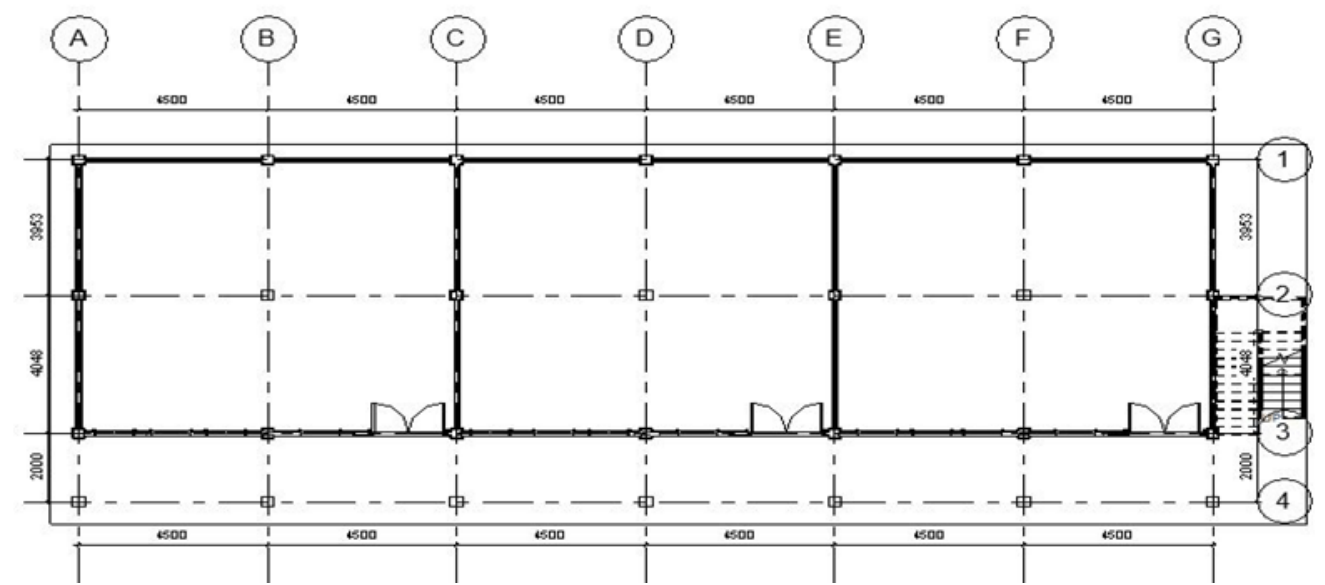

Gambar 2. Denah Arsitektur

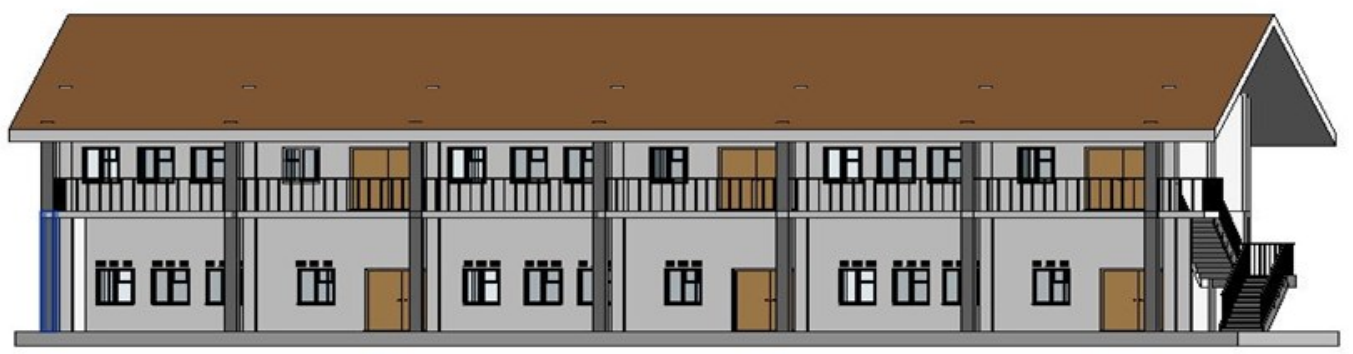

Gambar 3. Model Arsitektur 3D

\subsection{Kriteria Prencanaan}

Pada perencanaan gedung ini perlu beberapa informasi data sebagai ketentuan perencanaan. Informasi yang dibutuhkan diantaranya adalah jumlah lantai, luas bangunan, tinggi lantai, atap, dan material. Sebagai informasi awal dalam perencanaan struktur selanjutnya dijelaskan pada Tabel 1 .

Tabel 1. Informasi Bangunan

\begin{tabular}{cccc}
\hline \multicolumn{2}{c}{ Spesifikasi bangunan } & Spesifikasi bahan \\
\hline Fungsi Bangunan & Gedung Sekolah & Mutu Beton (f'c) & $25 \mathrm{Mpa}$ \\
Luas Bangunan & $216 \mathrm{~m} 2$ & Mutu Baja Tulangan (fy) Polos & $240 \mathrm{Mpa}$ \\
Jumlah Lantai & 2 Lantai & Mutu Baja Tulangan (fy) Ulir & $400 \mathrm{Mpa}$ \\
Tinggi Tiap Lantai & $4 \mathrm{~m}$ & \\
Kontruksi Atap & Rangka Kuda-kuda Baja Ringan & \\
Penutup Atap & Genteng tanah Liat & \\
\hline
\end{tabular}

Berdasarkan informasi awal tentang bangunan sebagai dasar dalam perencanaan struktur, selanjutnya perlu ditentukan dimensi struktur, dimensi struktur ini yang selanjutnya akan dianalisis apakah mampu menerima beban yang direncanakan. Pada penenentuan dimensi kolom dan balok harus mengacu dengan 
ketententuan SNI 2002 mengguanakan L/12 dan L/16 [11]. Rencana dimensi kolom dan balok seperti dijelaskan pada Tabel 2.

Tabel 2. Dimensi Kolom, Balok dan Plat Lantai

\begin{tabular}{cc}
\hline Uraian struktur & Dimensi \\
\hline Kolom Utama (K1) & $350 \mathrm{~mm} \times 350 \mathrm{~mm}$ \\
Balok induk (B1) & $350 \mathrm{~mm}$ x 200 mm \\
Plat lantai 2 & $120 \mathrm{~mm}$ \\
\hline
\end{tabular}

\subsection{Rencana Pembebanan}

\subsubsection{Rencana Beban Atap}

Rencana pembebanan perlu diperhitungkan terlebih dahulu sebagai dasar dalam analisis struktur sebagai parameter penentu bahwa suatu struktur dinyatakan kuat, yang dimaksud kuat adalah mampu menahan beban rencana [12]. Langkah awal dapat menghitung rencana beban atap. Untuk menghitung beban atap maka perlu ada data gambar atap meliputi denah atap, rencana kuda-kuda dan yang lainnya. Sebagai dasar menghitung rencana beban atap ditampilkan terlebih dahulu gambar atap dan kuda-kuda seperti ditampilkan pada Gambar 4 dan Gambar 5.

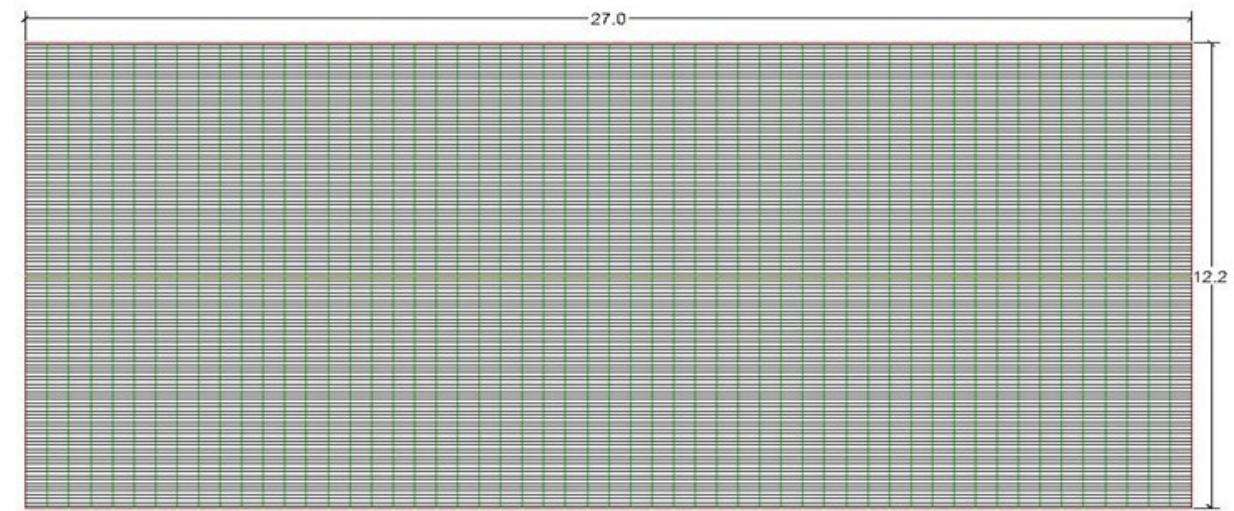

Gambar 4. Rencana Denah Atap

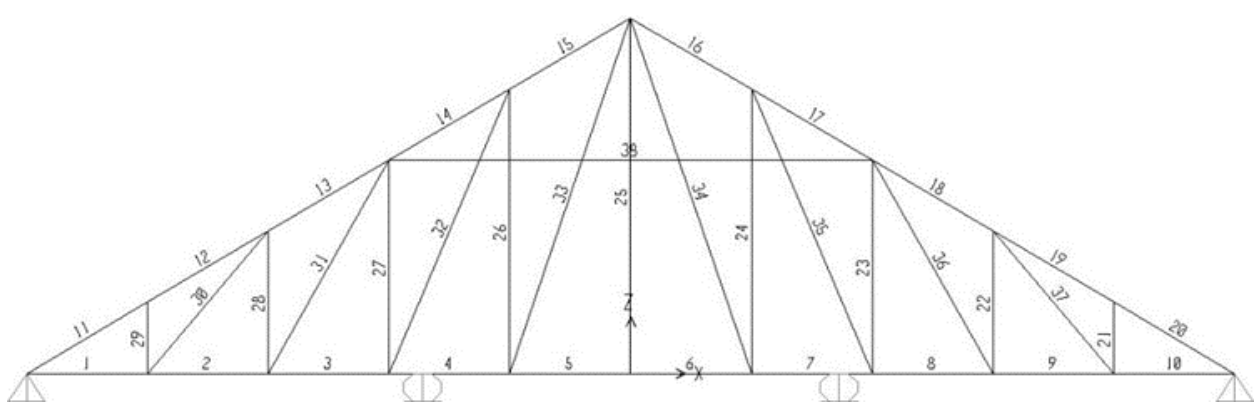

Gambar 5. Struktur Atap Rangka Baja Ringan

Sebelum menghitung beban atap terlebih dahulu perlu informasi tentang atap meliputi data spesifikasi teknis atap, luas atap dan seterusnya. Berdasarkan data-data tersebut selanjutnya dapat dihitung rencana pembebanan atap. Suatu contoh dalam menghitung beban angin pada atap diuraikan sebagai berikut; Sesuai SNI 1727-2013 [13], ditentukan nilai beban angin dalam kondisi normal adalah $40 \mathrm{~kg} / \mathrm{m} 2$ dengan kemiringan atap $\alpha=30 \mathrm{o}$

Koefisien angin tekan $=0,02 \cdot \alpha-0,4=(0,02 \times 30)-0,4=0,2$

Angin tekan $\mathrm{W} 1$ = luas $\mathrm{x}$ koefisien $\mathrm{x}$ beban angina tau dapat dihitung sebagai berikut:

$$
(1,2 \times 1,4) \times 0,2 \times 40 \mathrm{~kg} / \mathrm{m} 2
$$


$=13,44 \mathrm{~kg} / \mathrm{m} 2$

$\mathrm{W} 1 / 2=6,72 \mathrm{~kg} / \mathrm{m} 2$

Koefisien angin hisap $=-0,4$

Angin tekan W2 = luas $\mathrm{x}$ koefisien $\mathrm{x}$ beban angin

$$
\begin{aligned}
& =(1,2 \times 1,4) \times(-0,4) \times 40 \mathrm{~kg} / \mathrm{m} 2 \\
& =-26,88 \mathrm{~kg} / \mathrm{m} 2
\end{aligned}
$$

$\mathrm{W} 2 / 2=-13,44 \mathrm{~kg} / \mathrm{m} 2$

Berdasarkan perhitungan tersebut maka dapat diketahui bahwa beban tekan angin (W1 adalah 6,72 $\mathrm{kg} / \mathrm{m}^{2}$, dan beban hisap (W2) sebesar $-13,44 \mathrm{~kg} / \mathrm{m}^{2}$. Beban-beban lainnya dihitung berdasarkan ketentuan yang berlaku. Secara keseluruhan beban atap dapat dihitung menggunakan aplikasi computer sap2000 v16. Hasil perhitungan beban atap secara keselurhan di tampilkan pada Tabel 3.

Tabel 3. Hasil analisa pembebanan atap kuda-kuda baja ringan

\begin{tabular}{ccccc}
\hline Beban & Tumpuan Kiri & Tengah & Tengah & Tumpuan Kanan \\
\hline Beban Mati (Berat Sendiri) & 296,06 & 368,17 & 368,17 & 296,06 \\
Beban Hidup & 265,13 & 284,87 & 284,87 & 265,13 \\
Beban Angin Kiri & 10,89 & 25,15 & $-25,15$ & $-10,89$ \\
Beban Angin Kanan & $-10,89$ & $-25,15$ & 25,15 & 10,89 \\
Beban Hujan & 135,89 & 179,95 & 179,95 & 135,89 \\
\hline
\end{tabular}

\subsubsection{Pembebanan tangga}

Sebelum menghitung rencana beban tangga perlu ditampilkan terlebih dahulu .informasi tentang tangga, berikut ini disampaikan gambar rencana tangga yang di sajikan pada Gambar 6 .

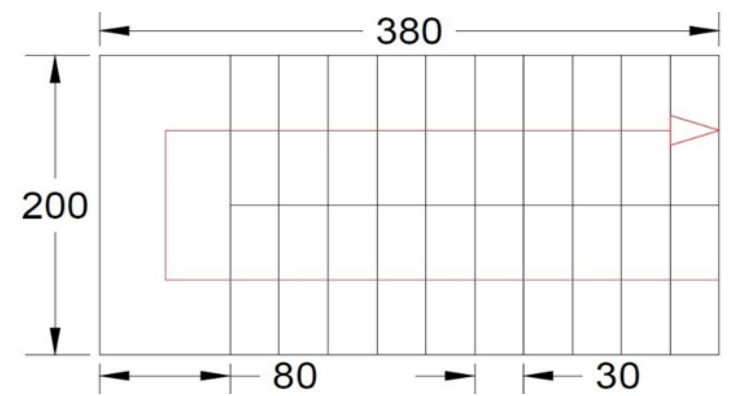

Gambar 6. Denah Tangga Rencana

Dari data gambar selanjutnya diidentifikasi spesifikasi teknis tentang tangga. Sebagia informasi awal mengenai tangga dijelaskan terlebih dahulu data tangga seperti ditampilkan pada Tabel 4.

Tabel 4. Informasi Tangga

\begin{tabular}{cc}
\hline Uraian spesifikasi Tangga & Dimensi \\
\hline Tinggi tangga & $400 \mathrm{~cm}$ \\
Panjang ruang tangga & $380 \mathrm{~cm}$ \\
Lebar tangga (Lt) & $100 \mathrm{~cm}$ \\
Tebal plat tangga (ht) & $12 \mathrm{~cm}$ \\
Tebal plat tangga bordes & $15 \mathrm{~cm}$ \\
Dimensi bordes & $80 \mathrm{~cm} \times 200 \mathrm{~cm}$ \\
Tinggi Optrade & $18 \mathrm{~cm}$ \\
Lebar Antrade & $30 \mathrm{~cm}$ \\
Jumlah antrade & $10 \mathrm{buah}$ \\
Jumlah optrade & $11 \mathrm{buah}$ \\
Jumlah anak tangga & 20 anak tangga \\
Kemiringan tangga $(\alpha)$ & $33,690 \mathrm{o}<350$ \\
\hline
\end{tabular}


Berdasarkan informasi tentang tangga seperti yang ditunjukan pada Gambar 6 dan Tabel 4, selanjutnya perlu dilakukan analisis tebal plat equivalen menggunakan Persamaan 5, Persamaan 6 dan Persamaan 7 sebagai berikut [14]:

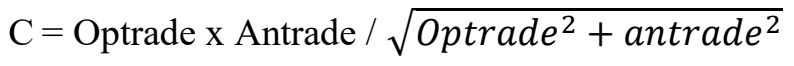

$$
\begin{aligned}
& =30 \times 18 / \sqrt{18^{2}+30^{2}} \\
& =15,43 \\
& \mathrm{t} \text { eq }=2 / 3 \times \mathrm{C} \\
& =2 / 3 \times 15,43 \\
& =10,29 \mathrm{~cm} \\
& \mathrm{Y}=\mathrm{t} \text { eq }+\mathrm{ht} \\
& =10,29+12 \\
& =22,29 \mathrm{~cm} \text { atau } 0,2229 \mathrm{~m}
\end{aligned}
$$

Total equivalen plat tangga berdasarkan analisis menggunakan Persamaan 5, 6 dan 7 membutuhkan $22,29 \mathrm{~cm}$.

Setelah dianalisis tebal plat equivalent selanjutnya perlu dihitung beban tangga, beban yang harus dihitung adalah beban mati (D) dan beban hidup (L). Menghitung beban mati seperti adalah sebagai berikut:

- Berat plat tangga $=0,2229 \times 1 \times 2400$ atau $534,96 \mathrm{Kg} / \mathrm{m}$

- Berat Spesi $(2 \mathrm{~cm})=0,02 \times 1 \times 2100$ atau $42 \mathrm{Kg} / \mathrm{m}$

- Berat keramik $(1 \mathrm{~cm})=0,01 \times 1 \times 1700$ atau $17 \mathrm{Kg} / \mathrm{m}$

Maka beban mati tangga (qD) adalah 593,96 Kg/m. Beban mati plat lantai tangga 593,96/cos fol $\alpha$ sehingga total beban mati tangga adalah $716,47 \mathrm{Kg} / \mathrm{m}$.

Selanjutnya menghitung beban hidup tangga mengacu pada (PPIUG' 83) faktor reduksi beban hidup pada tangga sebesar 0,75 [15], sehingga beban hidup tangga dihitung dengan $\mathrm{qL}=0,75\left(\begin{array}{lll}1 & \mathrm{x} & 300\end{array}\right)$ sehingga beban hidup tangga adalah $225 \mathrm{~kg} / \mathrm{m}$. Tangga memiliki kemiringan bidang, sehingga dari beban $225 \mathrm{~kg}$ selanjutnya dihitung bahwa beban hidup plat lantai tangga 225/ $\cos _{--1} \alpha=271,4 \mathrm{Kg} / \mathrm{m}$

Tangga memiliki bordes, sehingga perlu menghitung babean mati bordes serta beban hidup bordes. Perhitungan beban mati bordes diuraikan sebagai berikut:

- Berat plat tangga $=0,2229 \times 2 \times 2400$ atau $1070 \mathrm{Kg} / \mathrm{m}$

- Berat Spesi $(2 \mathrm{~cm})=0,02 \times 2 \times 2100$ atau $84 \mathrm{Kg} / \mathrm{m}$

- Berat keramik $(1 \mathrm{~cm})=0,01 \times 2 \times 1700$ atau $34 \mathrm{Kg} / \mathrm{m}$

- Maka jumlah beban mati bordes $(\mathrm{qD})=1188 \mathrm{Kg} / \mathrm{m}$

Sedangkan Beban hidup bordes berdasarkan (PPIUG' 83) faktor reduksi beban hidup pada tangga sebesar 0,75 [15], sehingga beban hidup bordes dihitung sebagai berikut:

$\mathrm{qL}=0,75(2 \times 300)$ maka beban hidup bordes adalah $450 \mathrm{~kg} / \mathrm{m}$.

\subsubsection{Beban Plat Lantai}

Tebal plat lantai 2 adalah $12 \mathrm{~cm}$ menggunakan bahan material beton bertulang, informasi dan perhitungan beban mati plat lantai di sajikan dalam Tabel 5 .

Tabel 5. Data Beban mati Plat Lantai

\begin{tabular}{ccc}
\hline Spesifikasi Plat Lantai & Cara Hitung Beban & Beban Mati (D) \\
\hline Berat sendiri plat lantai & $0,12 \times 2400$ & $288 \mathrm{~kg} / \mathrm{m}^{2}$ \\
Berat sendiri spesi $(2 \mathrm{~cm})$ & $0,02 \times 2100$ & $42 \mathrm{~kg} / \mathrm{m}^{2}$ \\
\hline
\end{tabular}




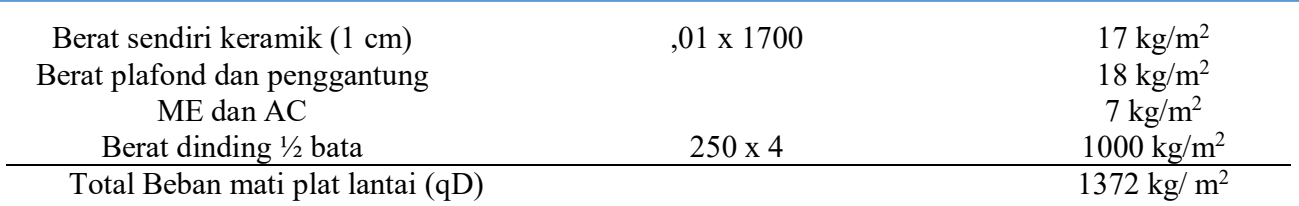

Beban hidup plat lantai yang direncanakan dan diperhitungkan adalah sebesar $250 \mathrm{~kg} / \mathrm{m}^{2}$. Beban ini disesuaikan dengan kegunaannya sebagai gedung sekolah.

\subsubsection{Beban Gempa}

Dalam perencanaan struktur perlu memperhitungkan beban-beban yang akan terjadi pada suatu bangunan Gedung diantaranya terdiri dari beban mati, beban hidup, beban angin, beban hujan, dan beban gempa. Menghitung beban gempa dapat menggunakan Persamaan 8 .

$$
\mathrm{SF}=\frac{I \cdot \mathrm{g}}{\mathrm{R}}=\frac{1.9,8}{8}=1,225
$$

g adalah percepatan gravitasi bumi dengan nilai 9,8; R merupakan nilai faktor daktilitas struktur SRPMK dengan nilai 8; dan I adalah faktor keutamaan Gedung dengan nilai 1.

Berdasarkan Persamaan 8 maka beban gempa arah X dan arah Y dapat dihitung sebagai berikut:

Arah-X:

$$
\begin{aligned}
& \mathrm{U} 1=\mathrm{X} \quad \mathrm{SF} \times(1)=\frac{I \cdot g}{R}=\frac{1 \cdot 9,8}{8}=1,225 \mathrm{~m} / \mathrm{s}^{2}(\text { gempa } 100 \%) \\
& \mathrm{U} 2=\mathrm{Y} S \mathrm{SF}_{\mathrm{x}}(0,3)=\frac{I \cdot g}{R}=\frac{1.9,8}{8}=0,368 \mathrm{~m} / \mathrm{s}^{2}(\text { gempa } 30 \%)
\end{aligned}
$$

Arah-Y:

$$
\begin{aligned}
& \mathrm{U} 2=\mathrm{Y} \quad \mathrm{SF} \times(1)=\frac{I \cdot g}{R}=\frac{1 \cdot 9,8}{8}=1,225 \mathrm{~m} / \mathrm{s}^{2}(\text { gempa } 100 \%) \\
& \mathrm{U} 1=\mathrm{X} \quad \mathrm{SF} \times(0,3)=\frac{I \cdot g}{R}=\frac{1.9,8}{8}=0,368 \mathrm{~m} / \mathrm{s}^{2}(\text { gempa } 30 \%)
\end{aligned}
$$

\subsection{Perencanaan Struktur Metode Konvensional}

Setelah menghitung beban rencana pada suatu struktur bangunan, selanjutnya perencanaan struktur dilakukan menggunakan metode konvensional. Informasi bangunan serta rencana pembebanan yang telah diuraikan sebelumnya menjadi data input untuk menghitung kekuatan struktur. Tahapan perencanaan struktur menggunakan metode konvensional secara ringkas di jelaskan pada ulur perencanaan Gambar 7 . 


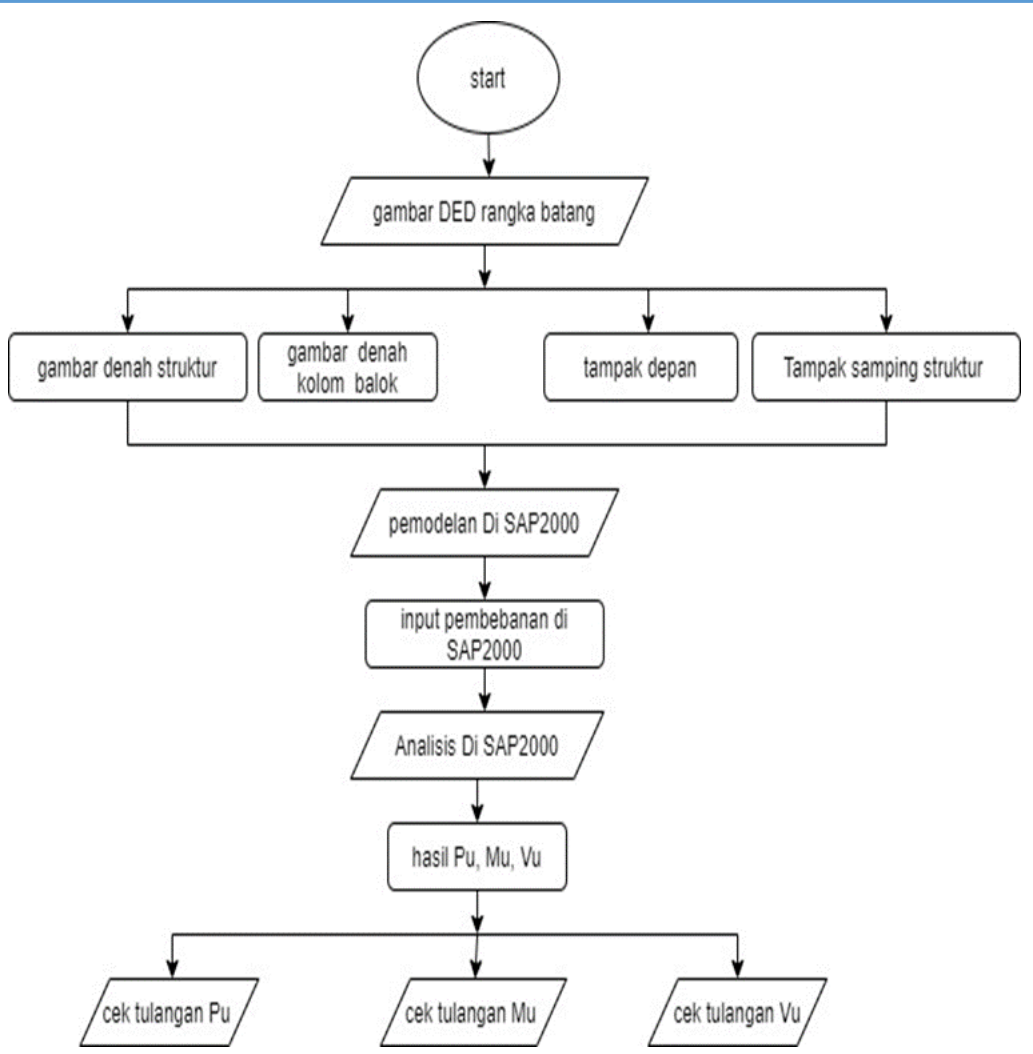

Gambar 7. Alur Perencanaan Struktur Metode Konvensional

Perencanaan struktur metode konvensional dengan tahapan seperti yang dijelaskan pada Gambar 7 , dengan dibantu aplikasi computer SAP2000 v14, dengan hasil analisa struktur menunjukan hasil pemodelan dan terbesar pada reaksi aksial $(\mathrm{Pu})$, momen $(\mathrm{Mu})$, dan geser $(\mathrm{Vu})$ pada dimensi yang telah dimodelkan sesuai dengan perencanaan sebelumnya kemudian dilakukan konfigurasi penulangan. Hasil pemodelan struktur seperti ditampilkan pada Gambar 8.

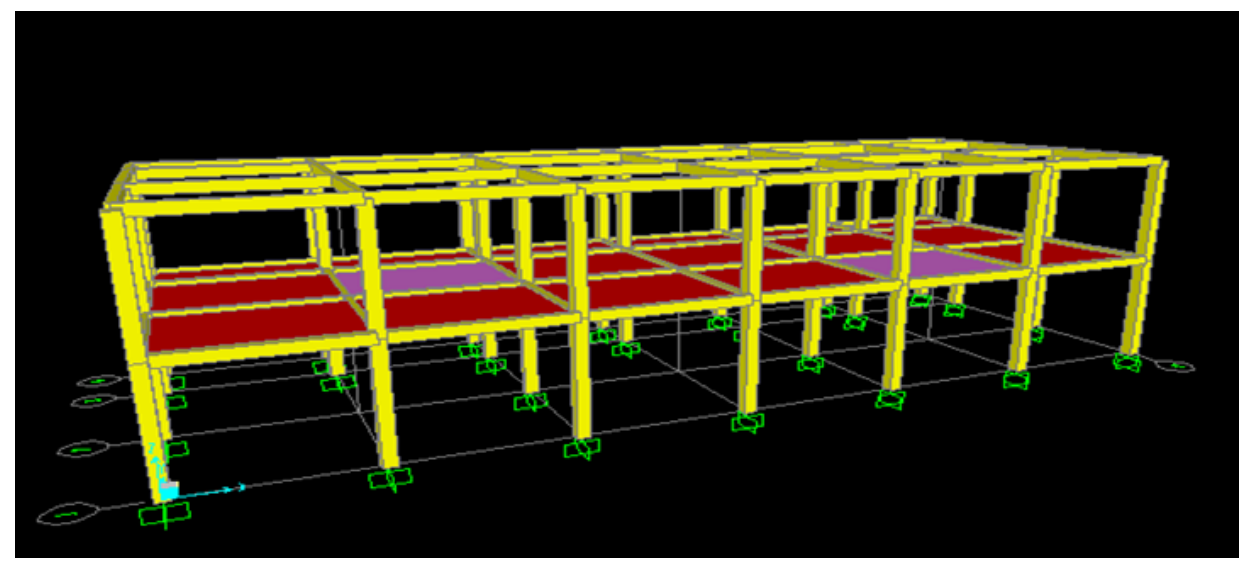

Gambar 8. Pemodelan Struktur 3D Frame Pada Aplikasi Computer

Berdasarkan hasil analisis dengan dibantu alat aplikasi computer, maka diketahui momen envelope balok akibat beban gravitasi dan beban gempa seperti di jelaskan pada Tabel 6 .

Tabel 6. Momen Envelope Balok Akibat Beban Gravitasi Dan Beban Gempa

\begin{tabular}{cccc}
\hline Kondisi & Lokasi & Arah goyangan & Mu (kN-m) \\
\hline 1 & Ujung Interior Negatif & Kanan & $-364 \mathrm{Kn}-\mathrm{m}$ \\
2 & Ujung Eksterior Negatif & kiri & $-364 \mathrm{Kn}-\mathrm{m}$ \\
3 & Ujung Eksterior Positif & Kanan & 182 \\
4 & Ujung Interior Positif & kiri & 182 \\
5 & Tengah BentangPositif & Kanan dan kiri & 216 \\
\hline
\end{tabular}


Setelah dilakukan pemodelan seperti pada Gambar 8 dan menghasilkan rencana pembebanan struktur seperti dijelaskan pada Tabel 6, mengacu pada SNI 03-2847-2013 Pasal 21.5.2.2 yang mensyaratkan bahwa kuat lentur positif komponen struktur lentur pada muka kolom tidak boleh lebih kecil dari $1 \frac{1}{2}$ kuat lentur negatif pada muka tersebut, sehingga didapatkan rencana penulangan struktur yang berada pada kondisi tanah keras sebagai berikut:

- Mu tumpuan atas balok: $364 \mathrm{kN}$ dipakai tulangan 4D19

- Mu tumpuan bawah balok: $182 \mathrm{kN}$ dipakai tulangan 3D16

- Mu tengah bentang balok: $216 \mathrm{kN}$ dipakai tulangan 3D16

- Sendi plastis pada balok terjadi pada $800 \mathrm{~mm}$ dari tiap-tiap ujung balok dan dipasang sengkang hoops dengan spasi $85 \mathrm{~mm}$

- Penulangan kolom $350 \mathrm{~mm}$ x $350 \mathrm{~mm}$ dipakai tulangan 8D22

- Sendi plastis pada kolom terjadi pada $600 \mathrm{~mm}$ dari muka tumpuan dan dipasang sengkang hoops dengan spasi $125 \mathrm{~mm}$.

\subsection{Perencanaan Struktur Menggunakan Aplikasi Berbasis Metode BIM}

Tahapan perencanaan struktur menggunakan aplikasi berbasis metode BIM melalui tahapan yang dijelaskan pada Gambar 9.

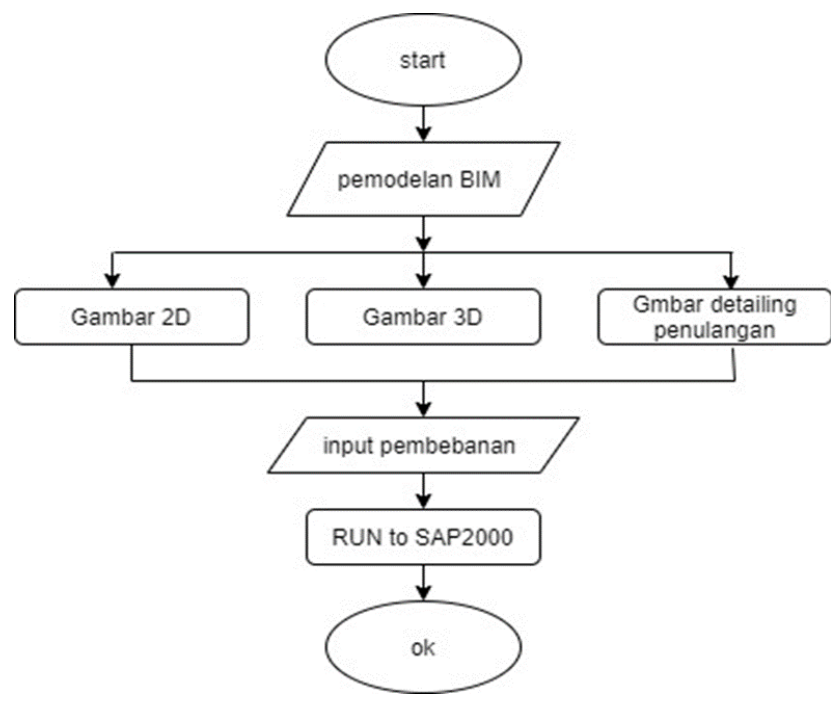

Gambar 9. Tahapan Perencanaan Struktur Menggunakan Aplikasi Berbasis Metode BIM

Perencanaan struktur menggunakan aplikasi yang berbasis metode BIM menghasilkan pemodelan struktur rangka batang seperti yang ditampilkan pada Gambar 10.

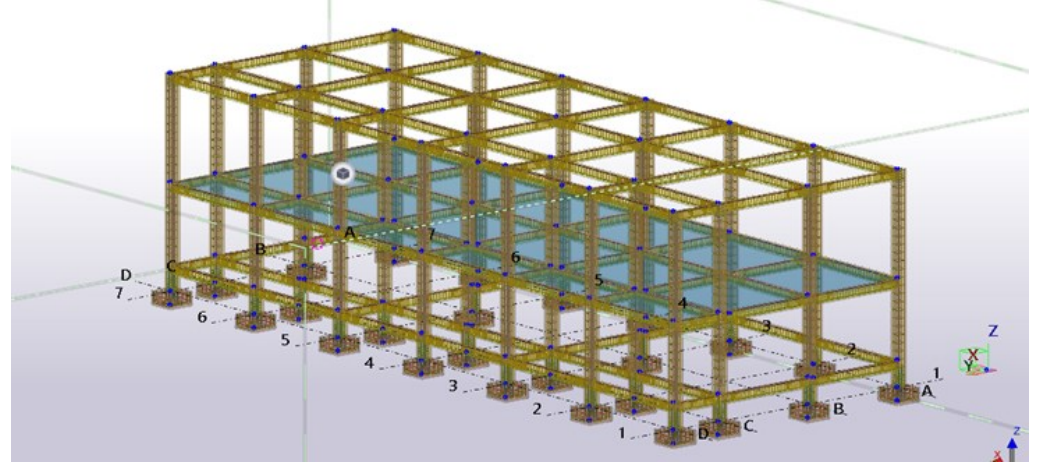

Gambar 10. Pemodelan Struktur Menggunakan Aplikasi Berbasis Metode BIM 
Pemodelan struktur menggunakan aplikasi computer berbasis metode BIM telah mendeteksi secara otomatis dimensi struktur serta detail penulangan struktur. Setelah selesai pemodelan selanjutnya detailling penulangan bisa di cek di aplikasi analisa struktur untuk menentukan kelayakan suatu struktur rangka batang beton bertulang tahan gempa menggunakan sistem aplikasi Building Information Modeling (BIM). Koreksi penulangan seperti dijelaskan hasilnya pada Gambar 11.

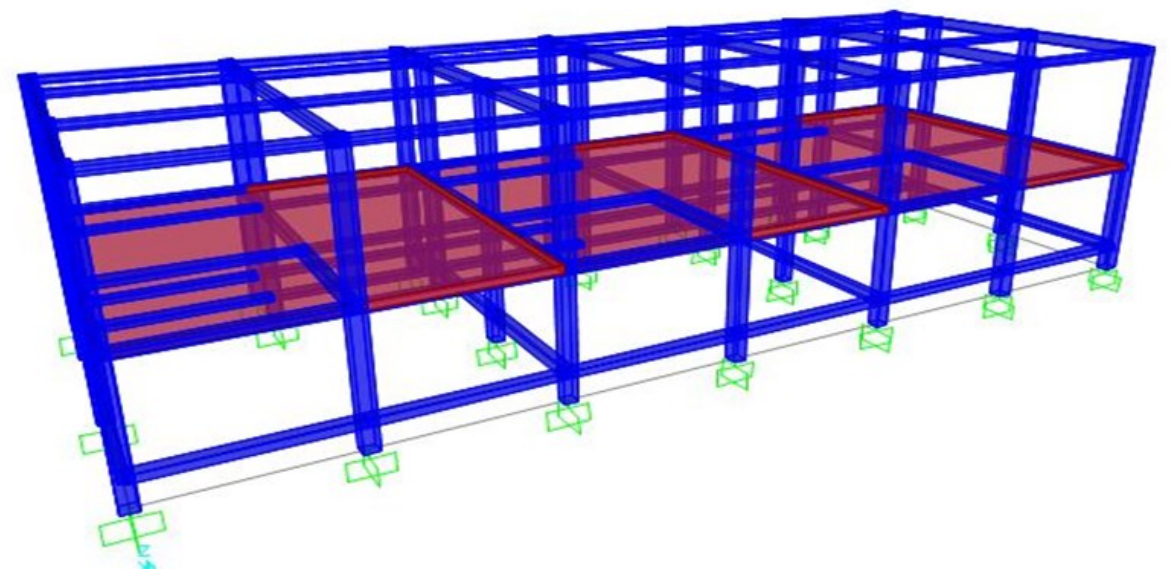

Gambar 11. Pemodelan Struktur 3D Frame Pada Aplikasi Computer Sap2000

Pemodelan struktur menggunakan aplikasi computer berbasis Building Information Modeling (BIM), kemudian dilakukan pengecekan menggunakan aplikasi komputer Sap2000, dinyatakan bahwa gaya yang dihasilkan ok, sehingga dapat dinyatakan bahwa metode Building Information Modeling (BIM) lebih praktis dan cepat dalam melaksanakan perencanaan struktur rangka batang, pemodelan, detailing model, dan langsung bisa dianalisis dengan combine dengan aplikasi analisa struktur. Level BIM yang digunakan dalam perencanaan struktur ini masuk ke dalam level 0 (baby level) dan level objeknya termasuk level design $2 \mathrm{D}$ dan $3 \mathrm{D}$ model.

\section{Kesimpulan}

Penelitian ini telah membandingkan perencanaan struktur menggunakan metode konvensional dengan metode BIM. Berdasarkan hasil eksperimen maka dapat dinyatakan bahwa metode Building information Modeling (BIM) mempunyai penentuan dalam penulangan secara otomatis membaca sesuai dimensi yang dibuat, dalam pemodelan cukup satu konsep, dan dapat berkolaborasi pada aplikasi non sistem BIM. Sedangkan metode konvensional dalam penentuan penulangan harus dicek tulangan, dan dalam pemodelan harus dilakukan satu persatu dan tidak dapat berkolabosi secara otomatis dengan system lain. Oleh karena itu aplikasi berbasis metode BIM dapat digunakan sebagai perencanaan dan pemodelan struktur rangka batang dengan lebih sederhana dibandingkan dengan menggunakan metode konvensional, sehingga disarankan bagi konsultan perencana, pelaksana konstruksi atau masyarakat secara umum untuk mengerjakan perencanaan struktur menggunakan metode BIM dan dapat memanfaatkan aplikasi yang telah memiliki metode berbasis BIM.

\section{Daftar Pustaka}

[1] P. H. Simatupang, T. M. W. Sir, J. F. A. Kompas, and V. A. Wadu, "Building Information Modeling (BIM) software pada perancangan gedung beton bertulang untuk mendukung industri 4.0 dalam bidang jasa konstruksi," SAINSTEK, vol. 4, no. 1, pp. 278-289, 2019. Available at: Google Scholar.

[2] I. Khambali and M. ST, Manajemen Penanggulangan Bencana. Penerbit Andi, 2017. Available at: Google Scholar

[3] A. Purwoko, "Studi Perbandingan Gaya Gempa Pada Struktur Bangunan Di Samarinda Berdasarkan SNI 03-17262002 dan SNI 03-1726-2012," KURVA S J. Mhs., vol. 1, no. 1, pp. 691-705, 2018. Available at: Google Scholar

[4] E. K. A. P. PERTIWI, "Studi Perkuatan Lentur Balok Beton Bertulang Variasi Overlapping Tulangan Di Seperdua Bentangan Dengan Metode Retrofit Menggunakan Wiremesh Dan SCC." Fakultas Teknik, Universitas Hasanuddin, 2018. Available at: Google Scholar 
[5] R. I. R. S. Putra, C. Suhendi, and A. M. Lestari, "Perencanaan gedung sekolah menengah atas dengan sistem pelat satu arah dan dua arah," J. TESLINK Tek. Sipil dan Lingkung., vol. 2, no. 1, pp. 15-22, 2020. doi: 10.52005/teslink.v1i2.12

[6] R. Hanapi and S. Sumarman, "Analisis perencanaan struktur gedung sekolah Pelita Bangsa Kota Cirebon menggunakan struktur beton SNI 2013," J. Konstr., vol. 6, no. 5, 2020. Available at: Google Scholar

[7] Y. A. Setiawan, "Analisa Perbandingan Kinerja Struktur Gedung Beton Bertulang Dengan Balok-Balok Kantilever Menggunakan Analisa Statik Ekivalen Non Linear (PushOver)." Universitas 17 Agustus 1945 Surabaya, 2020. doi: 10.30996/exp.v17i2.4429

[8] R. P. Adhi, A. Hidayat, and H. Nugroho, "Perbandingan efisiensi waktu, biaya, dan sumber daya manusia antara metode Building Information Modelling (BIM) dan konvensional (studi kasus: perencanaan gedung 20 lantai)," J. Karya Tek. Sipil, vol. 5, no. 2, pp. 220-229, 2016. Available at: Google Scholar

[9] M. A. Ghaffar, A. Soehardjono, and D. Nuralinah, "Perencanaan Ulang Struktur Gedung Tahan Gempa Menggunakan Metode Dinding Geser yang Mengacu Pada Sni-1726-2012 Pada Gedung Dekanat Fakultas Teknik Universitas Brawijaya," J. Mhs. Jur. Tek. Sipil, vol. 1, no. 1, p. pp-24, 2015. Available at: Google Scholar

[10] B. Mahendrayu and W. Kartini, "Sistem Rangka Pemikul Momen Khusus (Srpmk) Struktur Beton Bertulang Pada Gedung Graha Siantar Top Surabaya," Kern J. IIm. Tek. Sipil, vol. 2, no. 2, 2019. Available at: Google Scholar

[11] R. A. Prabowo, "Perencanaan pembangunan gedung dekanat Fakultas Teknik Universitas Negeri Semarang (struktur)." Universitas Negeri Semarang, 2015. Available at: Google Scholar

[12] A. Saputra and A. Firmanto, "Analisis Struktur Rumah Sakit Permata Cirebon," J. Konstr., vol. 6, no. 6, 2020. Available at: Google Scholar

[13] S. Soelarso, B. Baehaki, and A. Mursyidan, "Analisis Struktur Gedung Bertingkat Di Lima Wilayah Di Indonesia Terhadap Beban Gempa Dan Beban Angin Berdasarkan Sni 1726-2012 Dan Sni 1727-2013," Fondasi J. Tek. Sipil, vol. 6, no. 1, 2017. doi: 10.36055/ft.v6i1.2018

[14] D. Amanda and F. Anggraini, "Perencanaan gedung kuliah Jurusan Gizi Politeknik Kesehatan Palembang." Politeknik Negeri Sriwijaya, 2017. Available at: Google Scholar

[15] A. Putri, "Perencanaan Gedung Student Center Universitas Bangka Belitung." Universitas Bangka Belitung, 2018. Available at: Google Scholar 